\title{
( Maintaining Balance: A Comprehensive Look of aBe the Struggle between Government Protection and Reseach House Government Overreach in Regard to Mergers and Their Remedies
}

\author{
Severine Bateman \\ S J Quinney College of Law, University of Utah, 201 Presidents' Cir, Salt Lake City, UT 84112, USA \\ E-mail for correspondence: severine.bateman@law.utah.edu
}

\begin{abstract}
In September of 2020, the Department of Justice made a change to the Merger Remedies Manual, which discusses the correct remedies for mergers that violate the standards in the Heart-Scott-Rodino Act and how to best enforce them. A deeper look at this manual prompts a deeper analysis on current antitrust merger standards and how they balance government power and personal liberties. The Merger Remedies manual and its corresponding document with the Federal Trade Commission, as well as the merger standards in regard to the rise of Private Equity Buyers and Big Tech, promote concern over the balance between constitutional rights and promoting fairness in the marketplace. This article is among the first to analyze how current merger remedies stand in being effective in regard to the technology sector, while also analyzing the constitutionality of those merger regulations.

The article contributes to the literature in three primary ways. First, the article deeply analyzes the two manuals for merger remedies from the above mentioned agencies and determines which better balances governmental powers with personal liberties and where both agencies could improve. Second, the article outlines the current concerns with large technology companies and their current rights in regard to merger standards while also acknowledging their monopolizing tendencies, presenting ways in which such issues could more easily and constitutionally be regulated through antitrust merger laws. Third, the article analyzes the current stance from the merger regulating agencies towards private equity firms and how their changing stances and opinions support a less government-regulative stance towards private equity firm involvement.
\end{abstract}

Keywords: Mergers, remedy, antitrust, business, constitution, Facebook, amazon, big tech, government

\section{INTRODUCTION}

How much government intervention is too much? From the very foundation of this country, the people of the United States of America and its leaders have struggled with this question. While American citizens enjoy the rights they have to their various freedoms, there is also a recognizable need for government to step in and prevent grievous misdoings among the country's populace. One such place where this battle is fought out is over the economic sector. One of the government's chief concerns is guaranteeing that the marketplace keeps a certain standard of competitiveness. ${ }^{1}$ This standard is implemented to ensure that the marketplace

${ }^{1}$ See Department of Justice, Antitrust Division Home Page, https:/ / www.justice.gov/atr/about-division. is producing top quality services and goods. One area where threat to competitiveness is often seen is in the case of mergers. When one company starts buying up businesses within their market as well as other markets, competition decreases and these companies with monopolies in the marketplace start producing lower quality goods or enforcing rules for their goods that are not just for the American people ${ }^{2}$.

A rather well recognized example of this in the marketplace today is the expansion of Big tech. Companies like Facebook, Microsoft, Apple, and Amazon are entering into mergers not only in the tech sector, but also across other sectors of the economy. ${ }^{3}$ These mergers that could be deemed a threat to

\footnotetext{
${ }^{2}$ See supra note 1.

${ }^{3}$ See infra note 161 .
} 
competition in the marketplace must be dealt with, but not in a manner that infringes on constitutional rights. Along with the concerns brought on by big tech companies comes concern with another rising trend. As private equity firms and investors have become quite popular, the dynamics within the marketplace have changed drastically. ${ }^{4}$ Where mergers and company sell-offs used to be to competitors in the marketplace that aimed to continue operating the business for a long time to come, many private equity firms are instead investing in buyouts. These private equity investments concern some, who fear the private equity firms are simply looking to turn the business into as much of a profit maker as possible before selling. ${ }^{5}$ Because of this, any remedies for problematic mergers used to not consider private equity firms and investors as buyers. ${ }^{6}$ Recently, however, steps have been made to include such investors in the merger marketplace. ${ }^{7}$

Two government agencies have been developed to help combat the anticompetitive results of some marketplace mergers. ${ }^{8}$ The Antitrust Division of the Department of Justice (DOJ) is one such agency that has set up protocols to deal with the anticompetitive nature of some mergers. ${ }^{9}$ The other agency that gives regulation and policies to help preserve the competitive nature of the economic marketplace through merger monitoring is the Federal Trade Commission (FTC) ${ }^{10}$ Both agencies also strive to limit the amount of government intervention within merger details to prevent government overreach. ${ }^{11}$ While their methods are often similar, the two committees have some distinct differences. ${ }^{12}$ The two agencies have different manuals, but still with the same purpose, preserving the competitiveness of the market. ${ }^{13}$

The Department of Justice accomplishes this goal through the Merger Remedies Manual. ${ }^{14}$ The first version of the manual was published in 2004, while the newly revised manual was published in September of this year. ${ }^{15}$ In the revised version, the Antitrust Department listed six key principles the manual aims to fulfill. ${ }^{16}$ Under the Remedies Manual, the proposed

\footnotetext{
careers/09/private-equity.asp.

${ }^{5}$ See infra note 129, pg. 3 footnote 9.

${ }^{6}$ See infra note 19.

${ }^{7}$ See infra note 19.

${ }^{8}$ See supra note 1.

${ }^{9}$ See supra note 1.
}

4 See Understanding Private Equity, October 7, 2020 https://www.investopedia.com/articles/financial-

10 See FTC, Merger Review. https://www.ftc.gov/enforcement/merger-review.

${ }^{11}$ See infra note 39.

${ }^{12}$ See infra note 14 , whole manuals.

${ }^{13}$ See infra note 14.

14 See Merger Remedies Manual, Antitrust Division, U.S. Department of Justice, 2020. See at 2020 Merger Remedies Manual (justice.gov) [Merger Remedies Manual hereafter]. The manual has been updated three times since its conception, with the overall stance of the manual shifting with each update. Also, FTC, Negotiating Merger Remedies, Statement of the Bureau of remedies must preserve competition, should not create ongoing government regulation of the market, must not use temporary relief to remedy persistent competitive harm, avoid protecting competitors while still preserving competition, must be enforceable, and any risk associated with a failed remedy should fall on the companies involved, not on consumers. ${ }^{17}$

While the FTC Policy on Merger Remedies has most of the same goals as the Department of Justice's Merger Remedies Manual, the methods of the FTC lean more to prolonged government involvement after the mergers and remedies have been set. ${ }^{18}$ While the main purpose of the DOJ and the FTC are the same, the ways they go about protecting the competitiveness in the market do not offer the same balance between government intervention and freedom in the marketplace. While the agencies must also be wary of not becoming too involved in the marketplace, thereby resulting in the halting of a free market, the DOJ's manual for merger remedies does a better job at maintaining a balance. The FTC's more accepting stance to large government involvement is easily shown by the agency's higher tolerance level towards conduct remedies for mergers, which calls for certain conduct to be enforced within the companies after the remedies have been dispersed. While the DOJ's Merger Remedies Manual also allows for conduct remedies, it is only allowed under certain circumstances that meet a four part test for the conduct remedies. ${ }^{19}$ The Merger Remedies manual instead focuses on structural remedies, which involves the selling off of assets that would inhibit competition..$^{20}$

Along with favoring a remedy solution that limits the amount of government involvement while still effectively protecting the marketplace, the Merger Remedies Manual also does a better job of keeping the market open to competition by considering more favorably private equity buyers to participate in the buying of remedial sales of divestitures. Within the Merger Manual, the DOJ's antitrust division

Competition of the Federal Trade Commission, January 2012 [ hereafter the FTC Guidelines] FTC Merger Remedies Statement.

15 See supra note 14, cover.

16 See infra note 19, section "The Remedies Manual Provides a Roadmap to Merging Parties Outlining the Division's Intentions Regarding Enforcement of the Antitrust Laws as They Apply to Proposed Transactions".

${ }^{17}$ See supra note 16.

18 See infra note 19, section "Differences between DOJ and FTC Policy on Merger Remedies".

19 See DOJ Merger Remedies Manual Emphasizes Structural Remedies, September 23, 2020 DOI Merger Remedies Manual Emphasizes Structural Remedies $\mid$ Publications and Presentations $\mid$ Arnold \& Porter. Under the new manual, a behavioral remedy is only permissible if 1) "A transaction generates significant efficiencies that cannot be achieved without a merger; 2) a structural remedy is not possible; 3 ) the conduct remedy will completely cure the anticompetitive harm, and 4) the remedy can be enforced effectively."

${ }^{20}$ See supra note 19 , section "Remedies should be structured to avoid "red flags"". 
specifically points out how private equity buyers might sometimes be preferrable to strategic buyers. ${ }^{21}$ While the FTC does not have any strict rules against private equity buyers, Commissioners with the agency have expressed their hesitancy to allow private buyers to participate in divestiture purchases. ${ }^{22}$ The allowance of private equity buyers not only is a better policy to help keep the marketplace competitive, it also shows the DOJ's willingness to not overstep government's role in the remedies process.

The Merger Manual update also implies strict rules for how divestitures should be dealt with. ${ }^{23}$ In the manual, the DOJ points out specific courses of action for different divestiture suggestions as well as a step by step process of what a divestiture should include. ${ }^{24}$ The manual also points out exceptions to the typical model that may be used if the standard process cannot be followed. Meanwhile, the FTC policy leaves divestitures to occur as the remedy is worked out. ${ }^{25}$ While at first a less strict approach might seem to be obtaining a better balance between government intervention and maintaining competition, the strict structure on divestitures from the Department of Justice helps keep a standard for protecting competition in the marketplace that also leads to less government intervention in the long run. The stricter guidelines also allows for better monitoring of big tech mergers and creating divestitures that can compete in the space.

Although the new Merger Remedies Manual does strike a better balance between the role of government in protecting the competitive nature of the economic free market and the reach of government into the marketplace, there is still room for improvement. For instance, the manual calls for the DOJ's complete control on the transaction of the divestiture sale, including determining how the buyer will finance the purchase. ${ }^{26}$ Some could say this is an overreach of the entity's duties, while another could argue that it is necessary to preserve the competitive nature of the marketplace. Along with the manual, the Merger guidelines also need to be reviewed to assess how they handle the current issues with big-tech.

This article will proceed as follows. Part I will give background on the construction of the Federal Trade Commission and the antitrust laws that led to the creation of the Department of Justice's Antitrust Division as well as the two agencies' overall purpose in relation to divestitures. Part I will also briefly discuss the rise of the big tech and private equity buyer concerns. Part II will discuss the main reasons

\footnotetext{
${ }^{21}$ See supra note 14, pg. 24.

${ }^{22}$ See infra note 129.

${ }^{23}$ See supra note 14 Merger Remedies Manual, pg. 8-9.

${ }^{24} \mathrm{Id}$.

${ }^{25}$ See supra note 19, section "Differences Between DOJ and FTC Policy on Merger Remedies".

${ }^{26}$ See supra note 14 Merger Remedies Manual, pg. 26.

${ }^{27}$ See infra note 33 . The time period sets a backdrop for the rise of big business. Lots of innovation occurred because of the settling of the war and more cooperation between the north and south.
}

the new manual released by the department of Justice is better balanced at performing the combined duties of the two agencies. Part III will discuss where the manual is still lacking in obtaining the balance between protection and control and a discussion of what could be done to remedy the imbalance as well as curtail big tech monopolization and promote healthy private equity buying in mergers. Part IV will conclude the article.

\section{BACKGROUND}

The background Section is split into two parts. The first sections covers a brief history of how antitrust laws came to be as well as the laws that have resulted and where the law currently stands today. The second section covers the policy debate over antitrust law and where the debate sits today overall and where big-tech has found itself overly involved with the antitrust sector. The second section also discusses the concerns towards private equity buyers.

\section{A. The Start of Anti-Trust Laws}

Antitrust law became a concern in the legal world late into the 1800s. The laws came after a phenomenon started by the end of the American Civil War. ${ }^{27}$ The end of the war seemed to produce a great innovation frenzy around the country as new inventions popped up one after the other. ${ }^{28}$ Along with new inventions came new discoveries in profitable enterprises. Of these discoveries, the enterprise that produced the posterchild for antitrust law was the oil and gas industry. ${ }^{29}$ The industry started booming in Pennsylvania when new methods for refining petroleum were developed, whereafter many entrepreneur hopefuls rushed to make use of these inventions. ${ }^{30}$ However, the industry would come to be dominated by a single company formed in 1870, the Standard Oil Company. ${ }^{31}$ Eventually gaining control of $80 \%$ of the industry, this trust was just an example of trusts that had popped up all over the country in different industries. The general public, especially lawmakers, started to worry when just a handful of companies spread across these different sectors could essentially dictate the whole American marketplace. ${ }^{32}$

When congress assembled to put together legislation to stop the formation of all-controlling trusts in the marketplace, the Standard Oil Company (SOC) had acquired 22 of its 30 competitors in the oil industry through mergers and other methods. ${ }^{33}$ As the posterchild of powerful trusts, SOC had

\footnotetext{
${ }^{28}$ See infra 33.

${ }^{29}$ See Oil and Gas Industry: A Research Guide, Library of Congress, https://guides.loc.gov/oil-and-gas-industry/history. The industry was growing before the civil war, but trusts didn't really start forming till afterwards.

${ }^{30} \mathrm{Id}$.

${ }^{31} \mathrm{Id}$.

${ }^{32}$ See infra note 33.

${ }^{33}$ See Antitrust 1: Standard Oil, February 15, 2019, NPR (kuer 90.1) at https://www.npr.org/transcripts/695130695. The broadcast was the first in a week series coving the rise of trusts during the
} 
enough power and presence in the industry that they could easily shut down competitors by offering lower prices. ${ }^{34}$ SOC could also negotiate deals with other companies, such as railroad companies, to get better pricing on secondary needs for their products, such as transportation. ${ }^{35}$ Seeing all of the power being wielded by a handful of companies in the marketplace led congress to pass the Sherman Anti-Trust Act in $1890 .{ }^{36}$ The Act stood as a "comprehensive charter of economic liberty aimed at preserving free and unfettered competition as the rule of trade." ${ }^{37}$ Under the act, "every contract, combination, or conspiracy in restraint of trade," as well as any "monopolization, attempted monopolization, or conspiracy or combination to monopolize" was outlawed. ${ }^{38}$

At the time of the Act, the main focus of Congress was to split up the trusts that appeared to have taken over the marketplace. However, the language from the Act was very vague and appeared to allow government to reach their hand into the private sector whenever they saw something. ${ }^{39}$ The vagueness of the language in the law resulted in an onslaught of cases to determine questions such what exactly a conspiracy in restraint is, or if the government even had authority to restrict such actions. ${ }^{40}$ These cases led to opinions by the Supreme Court that clarified some of the language, such as opining that restraint of trade does not mean every restraint on trade, just those that could be deemed unreasonable. ${ }^{41}$

When faced with determining whether the passage of such an Act was constitutional, some of the cases brought before the courts resulted in exceptions that the Supreme Court found were necessary to abide by the constitution. ${ }^{42}$ For example, under the Noerr-Pennington Doctrine, it is made clear that businesses, as well as individuals, have the right to petition state government and local leaders to pass legislation that in theory would violate federal antitrust laws. ${ }^{43}$ The right to petition is guaranteed under the first amendment to the U.S. Constitution, so such petitioning at local levels must be allowed. ${ }^{44}$ On the same note, states are allowed, and many states have passed, laws that violate on its face federal

late 1800 s and the development of antitrust laws to combat those trusts.

${ }^{34}$ See supra 33 . Trusts are essentially companies within an industry that have consolidated into one company with seeming control of the industry through means such as acquisitions and mergers.

${ }^{35}$ See supra note 33

36 See FTC, Guide to Antitrust Laws: The Antitrust Laws, https://www.ftc.gov/tips-advice/competition-guidance/guideantitrust-laws/antitrust-laws.

${ }^{37} I d$.

${ }^{38} \mathrm{Id}$.

39 See Constitutional Constraints on Federal Antitrust Law. December 11, 2014, Constitutional Constraints on Federal Antitrust Law $\mid$ The Heritage Foundation.

${ }^{40}$ See supra note 36.

${ }^{41} I d$.

42 See supra note 39, Section "The Antitrust 'Petitioning' Immunity".

${ }^{43} I d$. antitrust laws. ${ }^{45}$ While many of these laws should, in theory, be preempted by conflicting with the Sherman Act, $\mathrm{m}$ the courts have found that the state laws, do not violate the Sherman Act and therefore can be law in their respective states, an attempt to avoid clashing with federalism and state powers. ${ }^{46}$

The sheer number of cases rising from the Sherman Act prompted the Department of Justice (DOJ) to create the position of Assistant Attorney General to handle all antitrust enforcement in 1903. ${ }^{47}$ However, even with an Attorney General focused solely on handling antitrust cases and the case law handed down by Supreme Court rulings, further clarification on the Sherman Act's purpose and more manpower to handle such issues were needed. The resulting legislation to handle a growing economic concern was the passage of the Federal Trade Commission Act and the Clayton Act in $1914 .{ }^{48}$ Under the Federal Trade Commission Act, the Federal Trade Commission (FTC) was formed and became responsible for enforcing federal antitrust laws along with the DOJ. ${ }^{49}$ Along with the formation of the FTC, the Federal Trade Commission Act also banned "unfair methods of competition" and "unfair or deceptive acts or practices. ${ }^{150}$ While the FTC Act is not officially an enforcer of the Sherman Act, any companies accused of violating the FTC act are also able to be accused of violating the Sherman Act. ${ }^{51}$

The Clayton Act passed in the same year effectively put into legislation laws that were meant to prevent the formation of large trusts through mergers. ${ }^{52}$ Under the Clayton Act, any acquisition where "the effect of such acquisition may be substantially to lessen competition, or to tend to create a monopoly" was prohibited..$^{53}$ Five years after the FTC Act and the Clayton Act, the DOJ created an antitrust division to deal with the increase of antitrust cases. ${ }^{54}$

As antitrust law continued to be developed, the Clayton Act underwent periodic revisions to include new concerns regarding anticompetitive behavior in the marketplace. One

${ }^{44} \mathrm{Id}$.

${ }^{45} \mathrm{Id}$.

${ }^{46} I d$.

${ }^{47}$ See supra note 1 . The number of antitrust cases at first were not large. As they started to grow, an attorney general dedicated to their review was needed. One attorney general was not enough, as clearly evidenced today by the robust FTC and antitrust division within the DOJ.

${ }^{48}$ See supra note 36.

${ }^{49} I d$. The role of the FTC later expanded to include some areas regulating competition that were not explicitly covered in the Sherman act.

${ }^{50} \mathrm{Id}$.

${ }^{51} \mathrm{Id}$.

${ }^{52}$ Id. The Clayton Act is rather large. The section dedicated to the analysis of mergers and acquisitions is Section 7 of the act.

${ }^{53} \mathrm{Id}$.

${ }^{54}$ See supra note 1. 
of these revisions, the Heart-Scott-Rodino Act (HSR), was passed to allow the government easier and faster access to knowledge about mergers that could negatively affect competition the marketplace. ${ }^{55}$ The HSR allowed for the creation of a premerger notification system that will alert the government to any mergers that pose a serious threat to competition in the marketplace based on the monetary potential of the transaction. ${ }^{56}$ Along with the passing of HSR, a large company now has five steps they must go through in order to result in a successful merger. ${ }^{57}$

The first step for a company big enough to impact competition in the marketplace is to file a premerger notification form through HSR. ${ }^{58}$ Companies are required to file this form depending on their results from three tests set up for merger transactions. The first test is the Commerce Test, where if either of the companies are engaged in any kind of activity that will affect commerce or in commerce itself, then the companies must do the next test. ${ }^{59}$ The second test is the Size of Transaction Test, where under this test, any merger that is valued under $\$ 50$ million does not need to file, but any merger valued over \$200 million must file with the HSR unless they meet an exemption. ${ }^{60}$ If the merger is valued between $\$ 50$ million and up to $\$ 200$ million, then the companies must go to the Size of Person Test. ${ }^{61}$ Under the Size of Person Test, a merger valued between $\$ 50$ million and up to $\$ 200$ million must report through the HSR if one of the parties has net annual sales of at least $\$ 100$ million and the other party has net sales of at least $\$ 10$ million. ${ }^{62}$ Under this test, two companies with net annual sales of $\$ 99$ million each would not need to

\footnotetext{
${ }^{55}$ See supra note 36 . The HSR act allowed the FTC and the DOJ to more easily ascertain which mergers were important enough to warrant review by the federal government. In theory, mergers involving small companies shouldn't affect competition in the marketplace. However, this is not completely accurate when the small company is acquired by a large company.

${ }^{56} \mathrm{Id}$.

${ }^{57}$ See infra note 58.
}

${ }^{58}$ See FTC, To File or Not to File When You Must File A Premerger Notification Report Form Report, Revised 2008. Introductory Guide 2- To File or Not to File When You Must File a Premerger Notification Report Form (ftc.gov) pg. 1.

${ }^{59}$ See supra note 58, pg. 2.

${ }^{60}$ See FTC, Steps for Determining Whether an HSR Filing is Required, https://www.ftc.gov/sites/default/ files/attachments/steps-determining-whether-hsr-filingrequired/stepstofile.pdf Note that the monetary values listed in the test are adjusted annually. Exemptions listed in note 63.

${ }^{61}$ See supra note 58, pg. $12-15$.

${ }^{62}$ See supra note 61.

${ }^{63}$ See supra note 58, pg.16. There are six exemptions to filing if the transaction is over $\$ 200$ million or meets the Size of Person test. The six exemptions are: 1) If a stock split in the merger does not "increase the percentages owned by any person...;2) Acquisitions of small percentages of issuer's voting securities solely for the purpose of investment are exempt; 3) Acquisitions of additional voting securities by persons who already hold 50 percent of the voting shares of an issuer are not reportable; 4) Acquisitions in the ordinary course of business, such as purchases of current supplies report their merger. Companies who meet these dollar thresholds must report to the HSR. ${ }^{63}$.

Step two is where the merger is cleared to either the DOJ or the FTC for review. ${ }^{64}$ There is no set formula for which agency takes on the case, even though the DOJ tends to take on more cases than the FTC. ${ }^{65}$ Steps three is where the agency that has taken the filing reviews the merger and either closes the investigation, allowing the merger to occur, or requests additional information from the two parties. ${ }^{66}$ Providing the additional information is step four. ${ }^{67}$ Step five is where the agency either closes the investigation and allows the merger to occur or declares the merger a violation of antitrust laws. ${ }^{68}$ In these circumstances, the parties either enter into negotiations with the agency where the agency will offer a consent decree that requires the merger to sell off assets or abide by other regulations, or the merger files a lawsuit or shows that that the merger isn't a violation of antitrust laws. ${ }^{69}$

Depending on multiple factors, this process can end up taking around two months. While each merger is unique, both the DOJ and the FTC have released documents streamlining the basics of what a remedy will include if needed and their recommended standards for reviewing remedial cases. ${ }^{70}$ The DOJ's Mergers Remedies Manual, which was initially released in 2004, was updated in September of 2020 while the FTC's policy towards merger remedies was last released in 2012. ${ }^{71}$

\section{B. Policy Concerns Over Anti-Trust laws and the influence of Big-Tech}

and usable durable goods....;5) Acquisitions of several categories of real property, such as unproductive real property, office and residential property, and hotels are not reportable.; 6) Acquisitions in regulated industries, whose competitive effects are reviewed by other agencies, may be exempt or subject to modified reporting requirements."

${ }^{64}$ See FTC, Premerger Notification and the Merger, Step Two: Clearance to One Antitrust Agency https://www.ftc.gov/tipsadvice/competition-guidance/guide-antitrust-

laws/mergers/premerger-notification-merger-review.

${ }^{65}$ See supra note, 64.

${ }^{66}$ See supra note 64, Step Three: Waiting Period Expires or Agency Issues Second Request. The agency can quicken the merger process by terminating the wait period before its expiration date. If not, and the agency finds no violations with the merger, the merger will take effect once the wait period expires. Additional Information may be requested if the agency believes the merger is in need of further investigation.

${ }^{67}$ See supra note 64, Step Four: Parties Substantially Comply with the Second Request. The agency then typically has thirty days to review the new information.

${ }^{68}$ See supra note 64: Step Five: The Waiting Period Expires or the Agency Challenges the Deal.

${ }^{69}$ See supra note 68.

70 See supra note 14, Merger Remedies Manual, and FTC Guidelines.

${ }^{71} \mathrm{Id}$. 
As antitrust laws have been in effect for over a century, the initial reasoning behind the need and purpose of antitrust laws and the public's concern with them has shifted. ${ }^{72}$ At the time of the Sherman Antitrust Acts' passing, the bills were passed with concern over the abuse of "big businesses" and "trusts" and aimed at protecting smaller businesses while effectively diminishing large business influences. ${ }^{73}$ However, at the time of the bill's passing, many people were worried over the constitutionality of involvement by the government in monitoring the competitiveness of the marketplace. ${ }^{74} \mathrm{On}$ the one hand, many scholars and members of the public found the act to be government's overreach into rights and privileges guaranteed to the citizens of the United States through the U.S. constitution. ${ }^{75}$ On the other, many recognized the need to curtail monopolization in the marketplace and argued that the law was necessary in order to maintain economic fairness. ${ }^{76}$ During the earlier years of antitrust law where it was often enforced, many felt that government overreach was winning out.

These views started changing in the 1970s and up to 2013, the antitrust laws were used more to promote consumer welfare and "economic efficiency" as opposed to controlling large businesses. ${ }^{77}$ This view saw market intervention through the use of Antitrust laws dwindle dramatically, with the DOJ and FTC enforcing antitrust laws sparingly. ${ }^{78}$ Mergers during this period were rarely challenged and the market was more left to itself and allowed for consumer demand to self-correct the market where a large market player started providing low quality goods or used bad business practices. ${ }^{79}$

During this time, a boom of innovation occurred in the marketplace quite similar to the one that occurred after the Civil War. This boom occurred mainly in the technology sector, where technology ranging from ecofriendly cars to seemingly all-purpose cellphones and the software on them came into existence. ${ }^{80}$ Many companies came to fruition and great levels of competition were had in a new sector of the

\footnotetext{
72 See infra note 77.

${ }^{73} \mathrm{Id}$.

${ }^{74}$ See supra note 39.

${ }^{75} \mathrm{Id}$.

${ }^{76} \mathrm{Id}$.
}

${ }^{77}$ See the Rise, Fall, and Rebirth of the U.S. Antitrust Movement, December 15, 2017 at https:// hbr.org/2017/12/the-rise-fall-andrebirth-of-the-u-s-antitrust-movement. The article discusses how often antitrust laws were enforced since their foundation. It's important to note that formation of large trust-like companies, such as big-tech companies like Facebook and Google, started acquiring other companies that would lead to their dominating presence in the marketplace during times of loose antitrust law enforcement.

${ }^{78}$ See supra note 77.

${ }^{79}$ See supra note 77.

${ }^{80}$ See How Big Tech became such a big target on Capitol Hill, October 10, 2020, https://www.cnbc.com/2020/10/10/how-bigtech-became-such-a-big-target-on-capitol-hill.html. These companies came to own large amounts of the marketplace over a span of roughly 20 years. economy. From this period of great innovation, a few companies quickly developed and soon found themselves in a similar place as the Standard Oil Company more than a century earlier. ${ }^{81}$ The rise of Facebook, Apple, Google, and even Amazon led to the coining of the term big-tech and, true to their nickname, these companies acted in similar Standard Oil fashion, acquiring and merging with other companies. ${ }^{82}$ With merges such as Google with YouTube, Facebook with Instagram, and Microsoft with LinkedIn, most consumers are currently in a situation where most of their day to day dealings and needs are done through or met by only a handful of companies. ${ }^{83}$

The rise of big-tech resulted in a shift of government use of the antitrust laws starting in 2014. Where there was before a laissez-faire stance from the government, the DOJ and FTC started enforcing the antitrust laws and regulations more harshly. ${ }^{84}$ After noticing the seeming takeover of big tech, the anti-monopoly sentiment present at the beginning of antitrust laws once again became prevalent, with such concern being showcased by the DOJ filing a lawsuit against the merger of AT\&T and Time Warner back in 2017. ${ }^{85}$ Ultimately, the merger was deemed valid by both the U.S. District Court and the U.S. Court of Appeals, but that suit is just one of many the DOJ and FTC have brought to fruition over the last few years. ${ }^{86}$ The two agencies have also been more proactive at stopping mergers before they happen and engaging in merger remediation. ${ }^{87}$

While both the DOJ and FTC have been making moves to be more active with Anti-trust laws, the agencies have also worked to preserve the balance between government intervention and personal freedoms in the marketplace. These efforts can be recognized in the system for merger remediation when a merger is deemed to interfere with the competitiveness of the marketplace.

${ }^{81} \mathrm{Id}$.

${ }^{82} \mathrm{Id}$.

${ }^{83}$ Especially in the timeframe of the pandemic, where many people did not leave their homes, stocks for most, if not all, of the big-tech companies soared. Amazon and Facebook especially saw an increase in net profits.

${ }^{84}$ See AT\&T and Time Warner Merger Case: What You Need to Know, Investopedia, December 7, 2018, see at https://www.investopedia.com/investing/att-and-timewarner-merger-case-what-you-need-

know/\#: :text=AT\%26T\%20first $\% 20$ announced $\% 20$ plans $\% 20$ to, Time \%20Warner\%20back\%20in\%202016.\&text=Bush\%20appoint ee $\% 2$ C $\% 20$ in $\% 20$ a $\% 20$ U.S. light $\% 20$ to $\% 20$ complete $\% 20$ their $\% 20$ merger. The case, which started back in 2017, was one of the first major antitrust cases tried since the climb of big-tech and was an expression of the antitrust agencies to companies that antitrust laws were going to be well enforced again. The DOJ ultimately lost, but the point had been made.

${ }^{85}$ See supra note 84.

${ }^{86}$ See supra note 84.

${ }^{87}$ See supra note 77. 


\section{Maintaining Balance of Purpose: The doJ MANUAL VS. THE FTC}

There are three recent changes made by the DOJ's Merger Remedies Manual that have brought the department closer to maintaining balance between protection of the marketplace and restricting government involvement. These changes have allowed the DOJ to move ahead of the FTC. This section is an analysis of these changes and how they better preserve the balance.

\section{A. The Preference for Structural Remediation}

The DOJ and the FTC are responsible for analyzing if a merger between two companies "may be substantially to lessen competition or to tend to create a monopoly." 88 When applicable, the DOJ or the FTC will further investigate and might challenge mergers that produce unilateral effects, could result in coordinated interaction, might get rid of potential competitors, or could result in causing competitors the inability to compete in the market. ${ }^{89}$

Unilateral effects usually occur when the only two competitors in a market want to merge..$^{90}$ A merger that would result in only two or three firms having a majority share in the market to the extent that an agreement between them would essentially destroy all competition in the market is considered challengeable on coordinated interaction. ${ }^{91} \mathrm{~A}$ merger that would stop a potential competitor from entering the market beforehand would be considered bad for competition and therefore challengeable. ${ }^{92} \mathrm{~A}$ merger of two companies in different markets but one that would make it impossible for others to compete, such as a company taking the only available supplier for bottles for pills, might also be challenged..$^{93}$ In such a case where the analysis of a merger leads either agency to determine that the merger would be anticompetitive, the two agencies will usually use structural or behavioral remedies to solve the issue. ${ }^{94}$

\footnotetext{
${ }^{88}$ See FTC, Guide to Antitrust Laws: Mergers: Competitive Effects. https://www.ftc.gov/tips-advice/competition-guidance/guideantitrust-laws/mergers/competitive-effects.

${ }^{89}$ See supra note 88.

90 See supra note 88, Horizontal Mergers: Unilateral Effects. Horizontal Mergers are mergers that are between two competitors in a marketplace, such as a merger between Facebook and Twitter.

${ }^{91}$ See supra note 88, Horizontal Mergers: Coordinated Interactions.

${ }^{92}$ See supra note 88, Potential Competition Mergers.

${ }^{93}$ See supra note 88, Vertical Mergers: Vertical Mergers occur when one of the merging parties obtains supplies for their product from the other party. An example would by Walmart acquiring one of their produce providers.

${ }^{94}$ See supra note 14, Merger Remedies Manual pg. 13, FTC guidelines pg. 5. In both manuals, reference to preferring structural remedies is given.

${ }^{95} \mathrm{Id}$.

${ }^{96} \mathrm{Id}$.
}

97 See supra note 14, Merger Remedies Manual pg. 8, FTC Guidelines pg. 5 note 6 . Other divestitures are permitted, just not
In structural remedies, the agency is aiming to keep the market competitive by forcing a divestiture, which is the sale of assets held by either company that would cause the market to become uncompetitive. ${ }^{95}$ The assets can be of both the tangible (e.g. buildings) and intangible (e.g. intellectual property) variety. ${ }^{96}$ However, both agencies prefer for the divestiture to include the sale of a stand-alone business with all of the framework, such as employees, already included. ${ }^{97}$ The stand-alone business format makes it easier for the divestiture buyer to compete with the newly merged parties after the completion of the merger. ${ }^{98}$ The DOJ has recently challenged a merger in New Hampshire, ordering Harvard Pilgrim Health Care to divest Tufts Health Freedom Plan Inc. before allowing Harvard Pilgrim's merger with Health Plan Holdings. ${ }^{99}$ The divestiture is being ordered in order to preserve competition in New Hampshire's health care industry, an industry that is already known for being one of the most expensive in the state when compared to the rest of the country. ${ }^{100}$ The DOJ has taken the stance that allowing the merger to happen without the divestiture would give Harvard Pilgrim enough sway in the healthcare market to easily dictate the price of Health Care in the state. ${ }^{101}$

While a structural remedy requires the sale of assets, a behavioral remedy instead focuses on the parties' conduct. $^{102}$ In a behavioral remedy, either agency will require the parties to abide by certain restrictions after the completion of the merger. ${ }^{103}$ These forced conduct restrictions can range from a variety of requirements, from non-discrimination provisions, restrictions towards certain contracting mechanisms, antiretaliation provisions, and forced licensing. ${ }^{104}$ However, behavioral remedies are consistently viewed as less effective than structural remedies. ${ }^{105}$ Both agencies view behavioral remedies as harder to implement, more likely to be circumvented, requiring more time and analysis from the

preferred. In the Merger Remedies Manual, usually close to extreme circumstances are needed in order to prefer a different divestiture situation.

${ }^{98} \mathrm{Id}$.

${ }^{99}$ The order was put into the New Hampshire District Court on $12 / 14$, so the final judgment ruling in favor of the DOJ will not be entered until then. See Justice Department Requires Divestiture of Tufts Health Freedom Plan In Order For Harvard Pilgrim and Health Plan Holdings to Proceed With Merger, December 14, 2020, Justice Department Requires Divestiture of Tufts Health Freedom Plan in Order for Harvard Pilgrim and Health Plan $\underline{\text { Holdings to Proceed With Merger }}$ | OPA | Department of Justice. ${ }^{100} \mathrm{Id}$.

${ }^{101} I d$.

102 See supra note 14, Mergers Remedies Manual pg.16, FTC Guidelines pg. 4.

${ }^{103} I d$. Such remedies are routinely seen as ineffective in the marketplace and harder to track.

${ }^{104} I d$.

${ }^{105} \mathrm{Id}$. 
agencies, and more expensive to monitor. ${ }^{106}$ In 2018, the FTC approved the acquisition of Orbital ATK, a developer of solid rockets, by Northrop Grumman, an aerospace and Defense Company, subject to four conduct/behavioral remedies Northrop Grumman would have to obey. ${ }^{107}$ Under the consent decree, the newly merged entity would have to appoint a compliance officer sent by the Department of Justice, as well as practice nondiscriminatory supplying of Orbital ATK products and services to competitors. ${ }^{108}$ The merger would also be required to adopt a compliance program and submit compliance reports on a regular basis to the FTC, the compliance officer, and the DOD. ${ }^{109}$

From the mission statements under the DOJ Antitrust Division and the FTC, the agencies aim to promote competition and maintain the U.S.'s free market economy by enforcing the antitrust laws to protect consumers while also respecting the liberties guaranteed to company owners under the constitution. ${ }^{110}$ Along with this promotion of competition, antitrust laws are seen as being enforced to promote economy efficiency, in which the promotion of competition and market efficiency requires the efficient protection of competition in the marketplace. ${ }^{111}$ However, while also promoting a competitive market, all antitrust related agencies must also strive to avoid too much government involvement. ${ }^{112}$ In consideration of the above remedies, the DOJ does a better job of maintaining the balance between competition promotion and government involvement.

While both agencies prefer structural remedies over behavioral remedies, the FTC is much more likely to allow the use of behavioral remedies over structural remedies. Because of the foreseen drawbacks of behavioral remedies, in the DOJ's new manual, a behavioral remedy is used only if a series of certain circumstances are met which even then, calls for the behavioral remedies to be used sparingly. ${ }^{113}$ While the FTC also does not use behavioral remedies often, it is much more likely to than the DOJ. ${ }^{114}$ The more likely use of behavioral remedies by the FTC is not as efficient and/or effective at preserving competition in the marketplace as the DOJ's strict adherence to structural remedies. Whereas the FTC has an $80 \%$ successful completion rate, roughly $85 \%$ of the remedies are purely divestitures. ${ }^{115}$ The extra time and money required to ensure a behavioral remedy is being carried out properly drains valuable resources from the FTC. Along with being a drain on the agency, it is also easier for parties participating in

\footnotetext{
${ }^{106}$ This is because of the nature of most conduct remedies. They usually require reporting or at least yearly checking, unlike a structural remedy, which is completed once the divestiture is sold.

${ }^{107}$ See Why FTC Accepted Conduct Remedies in Northrop Deal, June 15, 2018, https://www.arnoldporter.com/en/perspectives/publications/ 2018/06/why-ftc-accepted-conduct-remedies-in-northrop-deal. ${ }^{108} \mathrm{Id}$.

${ }^{109} \mathrm{Id}$.

${ }^{110}$ See supra note 1.

${ }^{111}$ See supra note 1.

112 See supra note 39.
}

the merger to circumvent any conduct restrictions the agency could enforce than it is to get around a sale of assets. Also, simple conduct remedies still allows the assets that were the subject of competition concerns to remain with the competitor, which means the competitor, through other means, might still be able to stifle competition in the marketplace.

The staunch stance on structural remedies also allows for more efficient preserving of competition in the marketplace because it is easier to track any violation of ordered divestitures and penalize merged companies that do not abide by the conditions set in the consent decree than to do the same for behavioral remedies. In July of 2020, Alimentation CoucheTard Inc. had to pay $\$ 3.5$ million for failing to sell a divestiture within the timeframe given by the FTC resulting from its merger to Holiday Station Stores, Inc. ${ }^{116}$ Determining whether a divestiture has been sold or not is much simpler and easier to discern than determining if a conduct restriction has been obeyed or not simply due to the fact that a divestiture sale should be reflected in the marketplace without having to go through the company's business files. The increased simplicity from structural remedies allows the FTC and DOJ to promote competition more effectively in the marketplace.

Along with better preserving competition practices, the DOJ manual's stronger preference for structural remedies helps the DOJ better avoid over-involvement on behalf of the government in the marketplace. With structural remedies, the role of the agency is finished once the divestitures are sold, unless the order was not followed through. However, with behavioral remedies, the parties in the merger will likely be heavily regulated by government officials for possibly years after the close of the merger. With the behavioral remedies ordered on Northrop, not only was the company under obligation to allow an official from the Department of Defense to consistently analyze every transaction and deal made in regards to Orbit ATK acquisition materials, Northrup also had to set up a compliance program and provide ongoing reports on how the company is doing in complying with the behavioral conduct remedies. ${ }^{117}$ However, not only was Northrup more burdened with constant government oversight of forced regulations, the information for violation of these regulations was only as good as the very attentive and interested eye of the official posted at the company or the reader of the consent reports.

\footnotetext{
${ }^{113}$ See supra note 29.

${ }^{114}$ See supra note 29.

115 See FTC, The FTC's Merger Remedies 2006-2012, A Report of the Bureaus of Competition and Economics, https://www.ftc.gov/system/files/documents/reports/ftcsmerger-remedies-2006-2012-report-bureaus-competitioneconomics/p143100_ftc_merger_remedies_2006-2012.pdf, pg.2.

116 See FTC and DOJ Enforcement Actions Highlight Scrutiny of Divestiture Orders Compliance, August 21, 2020 at https:// www.skadden.com/insights/publications/2020/08/ftcand-doj-enforcement-actions. This case along with many others highlights the ease of enforcement for violated divestiture fallouts.

117 See supra note 107.
} 
While the forced divestiture of part of the companies might at first glance seem more intrusive than behavioral remedies for a merger, in the long run it is actually less intrusive. This is due to the fact that after the divestment has been sold, the agencies no longer have any influence on the merger. Aside from the divestiture Alimentation Couche-Tard Inc. was ordered to perform and a check up on whether the asset had been divested, there was no more interaction with the FTC. ${ }^{118}$ However, in the case of Northrup, some behavioral remedies enforced resulted in constant government interaction and monitoring. ${ }^{119}$ Instead of a onetime event forced by the government, the merger instead is subjected to constant government oversight for an undetermined period of time.

Along with causing more government involvement than is necessary in the company's operations, the government's advanced involvement in the running of the company, especially one that is confined to a single state, after an implementation of behavioral remedies could cause the agencies to possibly run into problems with federalism and state's rights, both which could make a claim for government overreach and involvement. By keeping a strict adherence to structural remedies, The Merger Remedies Manual does a better job at promoting market competition and avoiding the overinvolvement of government than the FTC policy because the manual effectively removes the threat to competition as well as prevents ongoing involvement on the side of the government that could eventually lead to problems.

\section{B. Preference Towards Divestiture Buyers}

Who buys a forced divestiture sale is as important as the parties forced to sell it as a result of the merger. In order to maintain competition in the marketplace, the buyer for the divestiture must have "both the means and the incentive to maintain the level of premerger competition in the market of concern." ${ }^{120}$ The goal of the divestiture is that whoever buys the divestiture will be able to compete in the market after buying it, allowing the preservation of competition in the marketplace. ${ }^{121}$ So, in order to be a buyer of a divestiture, you must participate as a

\footnotetext{
${ }^{118}$ See supra note 116.

${ }^{119}$ See supra note 107.

${ }^{120}$ See Antitrust Division Policy Guide to Merger Remedies, October 2004 edition, pg.9 https://www.justice.gov/atr/page/file/1175136/download. See also Ford Motor Co. v. United States, 405 U.S. 562, 573 (1972). ${ }^{121}$ See Merger Remedies Manual pg. 6. ${ }^{122} I d$.

${ }^{123}$ See Merger Remedies Manual pg.8, also FTC Guidelines pg.5.

${ }^{124}$ See Merger Remedies Manual pg. 24.

${ }^{125}$ While private equity buyers had been mentioned before and divestitures had been sold to private equity firms, they were still for the most part considered as less preferrable to strategic buyers. See infra note 129.

${ }^{126}$ See Paul Weiss Discusses the Effect of the DOJ's New Merger Remedy Guidance on Private Equity Purchasers, September 11, 2020, https://clsbluesky.law.columbia.edu/2020/09/11/paulweiss-discusses-the-effect-of-dojs-new-merger-remedyguidance-on-private-equity-purchasers/.
}

competitor in that market after the divestiture is bought. ${ }^{122}$ In order to make sure the buyer is competition ready immediately after purchase, both agencies lean towards divestitures consisting of a stand-alone business. ${ }^{123}$

In the latest update to the Mergers Remedy Manual, the DOJ Antitrust Division expressly suggested that in some instances, private equity buyers would be better suited to the purchase of a divestiture than strategic buyers. ${ }^{124}$ In no previous guidelines or policy releases has the DOJ or the FTC suggested that private equity purchasers could be preferred purchasers of purchase divestitures. ${ }^{125}$ The new update to the DOJ manual has three criteria for purchasers of a remedial divestiture, which is that any potential buyer of a divestiture must be in such a position that the "divestiture of the assets to the proposed purchaser must not itself cause a competitive harm"; the DOJ Antitrust division also "must be certain that the purchaser has the incentive to use the divestiture assets to compete in the relevant market"; and finally "the division will evaluate the 'fitness' of the proposed purchaser to ensure that the purchaser has sufficient financial capability to compete effectively in the market over the long term." ${ }^{126}$ As long as a buyer meets these standards, the potential buyer will be considered. ${ }^{127}$ As well as meeting the standards, the Merger Remedies Manual update also states that the purchaser will be determined based on merit rather than on comparison with other buyers. This standard also says that a buyer chosen must not be the best buyer to preserve competition, just one that is able to do so.

Private equity buyers are private investors, often consolidated into private equity groups, which have an interest in investing in various companies. ${ }^{128}$ Many in the investing community stigmatize such buyers as opportunists looking to turn a quick profit from a picked up investment. ${ }^{129}$ To be fair, many private equity investment firms have the track record to warrant such bias. ${ }^{130}$ In 2013, the acquisition of Dollar Thrifty Automotive Group by Hertz resulted in the divestiture of Advantage Renta-Car to a smaller private equity firm, which resulted in the divestiture filing for bankruptcy within the year. ${ }^{131}$ Because of

${ }^{127} I d$.

128 See Sell to a Strategic or a Private Equity Buyer? https://www.industrypro.com/insights/sell-to-a-strategic-or-aprivate-equity-buyer.

${ }^{129}$ See Statement of Commissioner Rohit Chopra In The Matter of Sycamore Partners, Staples, and Essendant, Com. File No. 1810180 (Jan. 28, 2019) available at https://www.ftc.gov/system/files/documents/public_stateme nts /1448335/181_0180_staples_essendant_chopra_statement_128-19 0.pdf. Chopra dissented from a majority opinion to give divestiture to Sycamore Partners, stating in footnote nine that private equity firms that take over firms hoping to gain money through a quick sellout of the firm. In the case, Sycamore Partners had a history of doing so to a company before the deal with Essendant.

${ }^{130}$ See supra note 129 . While it is true there is such a track record, there is no evidence of such divestiture purchases systematically underperforming purchases by strategic buyers.

131 See infra note 132. There was also another buyer with the Private Equity Firm in this divestiture, so it is uncertain whether 
private equity firms with such track records, opportunities to purchase divestitures usually went to strategic buyers. ${ }^{132}$ Strategic buyers are usually competitors in the same space as the divestiture that are interested in expanding their presence in the market and so would be active in running the divestiture after it is bought. ${ }^{133}$ Because strategic buyers were seen to have a greater interest in growing the business over private equity buyers, the strategic buyers would receive the divestiture. ${ }^{134}$ However, with the Mergers Remedy Manual's definite standard for divestiture purchasers and its proposed instances where a private equity buyer would perform better in the divestiture space than a strategic buyer, consideration of private equity buyers for divestitures is both a more efficient method to promote competition in the marketplace as well as a better method to limit the amount of government involvement in the economy.

In the FTC policy, there is no mention of private equity buyers. ${ }^{135}$ The FTC did a study of the 2006-2012 FTC Merger Remedies and found that in some instances, private equity buyers were better candidates for divestiture purchases than strategic buyers, significantly because private equity buyers were usually willing to spend more for the divestiture. ${ }^{136}$ Yet, despite this study, some members of the FTC board, such as Commissioner Rohit Chopra, find private equity buyers to be higher risk than strategic buyers and therefore less favorable for divestiture purchase. ${ }^{137}$

In keeping with the purpose of promoting competition in the marketplace, the DOJ's stance through the Merger Remedies Manual is better suited for encouraging competition than the FTC policy. The Merger Manual's standards for a divestiture buyer rests on the potential buyer's merits. Any buyer that shows the requisite ability and desire to operate the divestiture within the market can be considered. By allowing private equity buyers to engage in divestiture purchases, the $\mathrm{DOJ}$ is opening the market to more potential players, thereby enlarging the player field and allowing more competitors to be involved. The greater involvement in the market means more competition is available, thereby accomplishing the goals of both agencies. Meanwhile, the FTC's apparent stance towards preferring strategic buyers shuts out consumers in private equity firms from other portions of the market that, while not readily versed in, the investors have legitimate desire to enter and will strive to operate the divestiture well.

the bankruptcy situation was completely due to the private equity buyer.

132 See Private Equity Buyers as Divestiture Buyers: U.S. and Europe Perspectives, The Threshold, Spring 2019, at https://www.lw.com/thoughtLeadership/private-equitybuyers-divestiture-buyers-perspectives

${ }^{133}$ See supra note 128 . The acquisition tends to fit in more naturally because the buyers already have experience, so even if there is no lack of ambition towards competing with private equity buyers, strategic buyers naturally are more likely to run the divestiture successfully. The biggest benefit of private equity firms is the cashflow.

${ }^{134}$ Again, this is because of the natural fit between the strategic buyer and the divestiture.

${ }^{135}$ See FTC Guidelines, the whole manual.
This actually serves to do the reverse of promoting competition within the marketplace by cutting down on the number of competitors that wish to enter the playing field.

Consideration of private equity buyers is also better for the competitiveness of the marketplace because such buyers usually have the ability to provide more financing to the divestiture. While it is true that cases such as Hertz have occurred not infrequently, there have also been plenty of cases where a divestiture purchased by a private equity firm resulted in greater ability to compete in the marketplace. ${ }^{138}$ (One such example is the purchase of Meow Mix by private equity firm JW Childs' after it was sold off during the acquisition of Purina by Nestle in 2001). ${ }^{139}$ After the purchase, JW Childs led the divestiture in a steady $13 \%$ growth rate year after year and also released new products under the company. ${ }^{140}$ The greater financing of private equity firms allows them to contribute more greatly to the divestiture's growth and competitiveness in the marketplace. While the fear of the firm doing a quick turnaround is real, FTC Chairman Joe Simmons rightly said that not all equity buyers are the same and should be evaluated company by company. ${ }^{141}$ Along with such an example comes the fact that there is no conclusive evidence to show that divestitures purchased by private equity buyers perform worse than divestitures purchased by strategic buyers ${ }^{142}$. With the guidelines for choosing a buyer updated in the DOJ's new manual, the standards required for a buyer should separate quick turnaround investment groups from private equity firms that will truly help foster competition in the designated market.

The DOJ's stance towards private equity buyers also serves to limit government's involvement in the marketplace by limiting the government's control over who can competitively participate in the market. Where the original preference for strategic buyers keeps the market closed off to those not already participating in the competition of the specific marketplace, the acceptance of private equity buyers provides a larger base of market players to choose from, which in turn makes it harder for government to have control over which businesses will be able to acquire which businesses. It allows for the prevention of too much government involvement and ultimately more freedom for competition in the marketplace.

\section{Strict Divestiture Regulations}

${ }^{136}$ See supra note 115, pg. 24. Even with this study, the FTC did not make a shift to private equity buyers.

${ }^{137}$ See supra note 116 . Chopra is the only member who dissented, but comments from Joe Simmons also suggests the Chairman's hesitation toward private equity firms (see supra note 132).

${ }^{138}$ See supra note 132, at pg. 3 (Discussion of successful divestitures sold to private equity firms).

${ }^{139}$ See supra note 132, at pg. 3, footnote 6, (Simmons Discusses Private Equity firms and their differences).

${ }^{140} I d$.

${ }^{141}$ See supra note 132, at pg. 3, footnote 6, (Simmons Discusses Private Equity firms and their differences).

${ }^{142} I d$. 
When crafting a structural remedy for a merger that encourages anticompetitive practices, both agencies prefer for the divestiture created to be a stand-alone business. ${ }^{143}$ Standalone businesses are preferred because the divestiture comes prepared with all the necessary resources for the purchaser and the divestiture to be competitive in the market. ${ }^{144}$ However, divestitures that consists of an assembly of assets instead of a stand-alone business are sometimes permitted depending on the circumstances. ${ }^{145}$

The DOJ's position towards divestitures is decidedly strict. While divestitures without stand-alone businesses are permitted, they are considered for the most part a "red flag" divestiture. ${ }^{146}$ This insinuates that the divestiture is likely to fail as a competitor in the market. ${ }^{147}$ There are two main reasons why the DOJ takes this stance, with the first being because the sale of a divestiture without all of the assets that made it a successfully competitive participant in the market would suggest that the divestiture is entering the marketplace without being fully functional and able to perform. ${ }^{148}$ Expecting similar results and contribution to the competition of the marketplace from a divestiture that is not able to function on its own can be seen as a failure to preserve competition within the marketplace. ${ }^{149}$ Secondly, when a divestiture is being sold as a stand-alone business, the divestiture already has a history of performance within the marketplace, so it makes it possible for the DOJ to predict to a reasonable level of accuracy that the divestiture will be able to preserve competition within the industry its part of. ${ }^{150}$

The FTC, as a matter of policy, is more accepting of divestitures that aren't stand-alone businesses. ${ }^{151}$ Under the FTC guidelines, a divestiture that consists of enough assets for the divestiture to be successful in competing in the marketplace once functioning with the divestment purchaser is acceptable. ${ }^{152}$ This divestiture of many parts requires that, at the time of settlement between the FTC and the merging companies, the parties can demonstrate to the FTC how the divestiture could be incorporated into another business or what a business could add that would allow the divestiture to maintain a competitive stance in the market. ${ }^{153}$

The standard set forth by the DOJ is much more efficient at promoting competition than the FTC's policy. Most importantly, by requiring a full stand-alone business to be in the divestiture, the DOJ already has some foresight into how the divestiture will perform in the marketplace after the sale. With such foresight, the DOJ can reasonably determine whether the sale of the divestiture will preserve the

\footnotetext{
${ }^{143}$ See supra 14, Merger Remedies Manual pg. 8-9; FTC Guidelines pg. 5 .

${ }^{144} I d$.

${ }^{145}$ See supra 14, Merger Remedies Manual pg. 9, FTC Guidelines pg. 5.

${ }^{146}$ See supra note 19, Section "the Remedies Manual Provides A Roadmap to Merging Parties Outlining the Division's Intentions Regarding Enforcement of the Antitrust Laws as They Apply to Proposed Transactions".

${ }^{147}$ See supra note 14, Merger Remedies Manual, pg. 25 on failure of divestiture.
}

competition of the marketplace for the given industry, without giving benefit to one business over the other. Also, when the whole business is severed from both merger parties through a divestiture, there is no lingering entanglements that could lead to anticompetitive practices in the industry. The sale of a whole stand-alone business also helps prevent unnecessary and perchance undesirable interactions between the merger parties once the merger is complete.

While the initial stance of the DOJ might seem to be overextending the reach of government into company affairs, the stance actually serves to limit the government's interactions with the merger. Initially, the government would have a rather controlling hand on how the divestiture is to take place. However, in the aftermath, the government would be much less involved. If parties of the merger are able to keep certain assets from a business, these assets would likely be subject to some kind of conduct remediation, which would require the government to stay involved after the merger has been consummated to guarantee the conduct remedies are being followed. Even if there is no conduct merger suggested, the government still might find the need to check in on the merger parties to make sure any assets taken from the stand alone business are being used appropriately. This would lead to greater government involvement in the merger and the post-merger results, not less.

Overall, the Merger Remedy Manual newly released by the DOJ does a better job at maintaining the balance between government involvements in the marketplace and preserving economic competition than the current merger remedy policy of the FTC. While both policies prefer structural remedies, the Merger Remedy Manual holds a stronger requirement for divestitures and only allows conduct remedies, which are less efficient and more government-involved, when a four part test is met. ${ }^{154}$ The DOJ also opens up the competition to more potential buyers through its positive consideration of private equity buyers and encourages short-term involvement and competitiveness through strict requirements for stand-alone business divestitures.

\section{Further Analysis on Merger Remedies AND Merger Concerns in the MarketPlace}

While the DOJ does do a better job at maintaining a decent competition/government involvement balance for companies in the process of being acquired, there are still many areas where the Merger Remedy Manual seems to be lacking, so additions that could be made to better secure efficient promotion of competition along with limited government

\footnotetext{
148 See supra note 146, subsection "A. Remedies should be structured to avoid 'red flags'".

${ }^{149}$ The company has effectively been removed from marketplace competition, allowing the remaining companies greater hold in the market.

${ }^{150}$ See supra note 14, Merger Remedies Manual, bottom of page 8 .

${ }^{151}$ See FTC Guidelines pg. 5.

${ }^{152} \mathrm{Id}$.

${ }^{153} I d$.

${ }^{154}$ See supra note 19.
} 
involvement. Along with more changes to the two agencies' guidelines, some changes to the overall method of merger analysis and governance post-merger could be intuitive in order to deal with current rising issues, such as big-tech.

\section{A. Restriction on Intangible Assets Transfer}

An example of where the two sets of guidelines could be improved is where the manual prohibits the licensing of intangible assets after the merger process between the two merger parties. ${ }^{155}$

When Otto Bock HealthCare North America, Inc acquired Freedom, the courts expressed how allowing the merging firms to retain rights to intangible assets as well as grant those rights to the divestiture purchaser could cause problems in competition after the fact. ${ }^{156}$ While the FTC is willing to analyze the situation and sometimes allow multiple owners for the intangible property, the new DOJ manual takes a firm stance against it. ${ }^{157}$ Such a stance reflects the DOJ's position that the shared ownership would cause a lack of desire of competition for the newly purchased divestiture. ${ }^{158}$ While this may be true, this is not always the case. In some cases, such action can actually cause competition to slow because the newly merged company cannot function efficiently without the intangible assets. Also, requiring the companies to divest intangible property could be seen as an overreach by government.

The best solution to encourage competition while also limiting government oversight would be to give the divestment purchaser an opportunity to decide with the newly merged firm whether they wish to co-own the assets or establish a licensing fee. In this way, both companies will act in the way that is best for them and most likely reach an agreement that will promote competition in the marketplace.

\section{B. Restrictions on Private Equity Buyers}

Another issue for the DOJ and FTC to consider is the use of private equity buyers. While the DOJ now looks favorably upon using such buyers for divestiture purchases where appropriate, the FTC still has a stigma against such buyers, as do many consumers in the marketplace. ${ }^{159}$ It is also true that there is past evidence of private equity buyers purchasing divestments just to turn around and sell them. ${ }^{160}$ The public's opinion of such a purchase could affect how the company performs, which could lead to the company not being able to be competitive in the market. A good way to combat such issues would be to require a one year, two year, and/or five

\footnotetext{
${ }^{155}$ See Merger Remedies Guideline pg. 13. In some circumstances, the licensing may be permitted, but the licensing must be nonexclusive and such cases are rare.

${ }^{156}$ See FTC, GCR Live $9^{\text {th }}$ Annual Antitrust Law Leaders Forum; Fixer Upper: Using the FTC's Remedial Toolbox to Restore Competition, February 8, 2020, pg. 5 https://www.ftc.gov/system/files/documents/public_stateme nts $/ 1565915 /$ conner gcr live conduct remedies 2-8-20.pdf.

${ }^{157}$ See supra note 155.

${ }^{158} \mathrm{Id}$.

${ }^{159}$ See supra note 116.

${ }^{160}$ See supra note 116 .
}

year review of private equity firm-bought divestitures to make sure they are competing in the marketplace. Such a review system would encourage the equity firms to remain competitive, especially if the reviews came with a fee to be paid if lack of effort to be competitive was found.

On the other hand, such a program could be seen as overreach by the government. Also, not all private equity firms are alike. The best way to resolve concerns of government overreach as well as recognize the difference between private equity companies would be to make the reviews mandatory only for private equity buyers that have a history of quickly selling divestitures. Depending on the FTC's and DOJ's concern towards the private equity buyers in question, the agencies could also elect whether to do all three reviews for the company or whether to just do a single review. The reviews could even be extended to any potential buyer that presents itself as being at high risk for removing the divestiture from competition.

While the policy on its face seems like more of a conduct remedy and equivalent to government overreach, the policy would make the agencies' task of preserving competition in the marketplace easier by better surveying potential buyers and encouraging divestitures to remain competitive in the marketplace. The policy would also only target buyers chosen that are suitable but appear to be high risk. Also, depending on the number of reviews required, government involvement could be minimal and most definitely comes to an end after five years, an end that is not as foreseeable in many other conduct remedies.

\section{Retroactive Challenges to Mergers}

The seeming rise of big-tech has created many concerns for the FTC and the DOJ. Mergers that seemed to be between small companies and therefore not reported through the HSR system resulted in companies like Facebook and Apple obtaining influence in the market to such a degree that their power would seem to cause an imbalance and could easily lead to a decrease of competition in the marketplace. ${ }^{161}$ Along with orchestrating many smaller mergers, big-tech companies also orchestrated larger mergers that, at first passing through the HSR review system, did not seem to pose a threat to competition in the marketplace. ${ }^{162}$ However, with the seeming power these companies hold today, the antitrust agencies, especially the FTC, are trying to curtail that power through seemingly retroactive action. ${ }^{163}$

$\begin{array}{llr}{ }^{161} \text { See Scrutiny of Tech Piles Up with Review of Small Deals, } \\ \text { Bloomberg, } & \text { February } & 12,\end{array}$ https://www.bloomberg.com/news/articles/2020-02-12/bigtech-s-smallest-deals-get-new-antitrust-scrutiny.

${ }^{162}$ See supra note 161. Along with the with Facebook acquiring WhatsApp and Instagram, Microsoft acquired LinkedIn in 2016 and Amazon acquired Whole Foods in 2017. While all of these were major deals, the markets between the two companies were considered different, especially in the case of Amazon acquiring whole foods.

${ }^{163}$ See Facebook Breakup Would Demolish Zuckerberg's Social Media Empire, December 9, 2020, https://www.bloomberg.com/news/articles/2020-1210/facebook-breakup-would-demolish-zuckerberg-s-social- 
In December of 2020, the FTC sued Facebook for "abusing its monopoly powers in social networking to stifle competition." 164 The primary target of this claim was that two recent acquisitions by the tech mogul, Instagram in 2012 followed by WhatsApp two years later, were acquisitions meant to take care of competitive threats against Facebook. ${ }^{165}$ However, under all the factors usually considered under HSR review, the claim of getting rid of competition does not quite seem to fit. Instagram and WhatsApp were not the only other competitors in the field, as twitter and other social media platforms are still in use. Also, presumably at the time of these mergers, the total percentage of the market Facebook would be in control over after the merger did not raise concern for coordination between agencies in the department that reviewed the merger. The mergers also did not prevent potential competitors from entering the marketplace, and Facebook obviously did not destroy the competitors as both Instagram and WhatsApp are well known and fairly popular, one even more popular than its new parent company amongst the younger generation.

While it is true that Facebook armed with these new additions currently holds significant sway in the tech industry, enough to possibly create an atmosphere for anticompetitive measures, at the time of the mergers the company did not. To do a retroactive look on all of the mergers done by big-tech companies and force breakups when there was no obvious sign of anticompetitive measures being forced on other companies would be on overreach by government. However, that does not mean the government should completely ignore the current power bigtech companies hold. Instead, the agencies should focus on two preexisting modes for curtailing mergers that lead to monopolies and make changes to better stop such mergers.

\section{Restructuring the qualifications for HSR filing.}

The current standards for analyzing whether a merger needs to be filed under the HSR system states that any set of companies where, even if the merger is valued between $\$ 50$ million and \$200 million, doesn't pass $\$ 10$ million net annual sales on the smaller company's end doesn't need to be reported. ${ }^{166}$ Under such a reporting system, a start-up that has groundbreaking technology in an industry can be acquired without having to file if the start-up has yet to have sales or hasn't been able to get enough sales to qualify. In this way, companies like Facebook and Amazon are able to acquire companies that at first glance would not violate the HSR standards. This is due to the fact that large tech companies acquire smaller companies with little to no revenue. However, those smaller companies have services or technology that, if given enough starting capital, will allow larger tech companies to effectively control the technology market. The small sizes of these other companies keep them from being readily noticeable by the DOJ and FTC, allowing big tech more control of the market. ${ }^{167}$

media-empire. Facebook's acquisition of WhatsApp and Instagram occurred around the same time period as many acquisitions by major tech companies, but Facebook's acquired companies look more like they could have been competitors than most of the other acquisitions at the time.

${ }^{164} I d$.
The best way to curtail the rampant acquisition of companies by big-tech is to amend the reporting standard so that companies valued at a certain amount, or companies that have a certain percentage of control in the merging market, must report the merger through the HSR system, regardless of the other company's size or any exemptions currently allowed. Doing so will ensure that all of the mergers being done by these companies comes under inspection of the DOJ, so mergers that initially might seem fine can be further analyzed. Such further analysis could show potential violations of competitiveness in the marketplace that otherwise may have gone unnoticed.

At first glance, such policy might seem like overreach on the part of the government in regard to large companies. However, such policy stands in the same sentiment as when antitrust law was first established back in $1890 .{ }^{168}$ Companies that have grown large enough that they can control parts of the market so readily can easily rid their industries of competitors if they acquire all of their competitors before they're big enough to report the acquisition to the FTC or DOJ. Such a policy is also less intrusive than the current stance of going into these companies and forcing divestitures of companies that would not be as valuable as they are today without the assistance of the big-tech companies that acquired them.

\section{Stronger focus on Coordinated Interactions}

Another method of curtailing anticompetitive action between big tech companies without intrusively breaking up the companies that were legally allowed to form up to this point is to bring the coordinated interactions analysis for mergers more to the forefront of analysis of these businesses' interactions between each other. When analyzing for coordinated interactions to determine if a merger would be anticompetitive, the FTC and DOJ check to see if allowing such a merger would result in a situation where there were few enough competitors that the newly merged entity could negotiate an agreement with the other major market shareholder in the industry, to the degree that all the other competitors would not be able to effectively compete. ${ }^{169}$ While applying the standard to companies that have already been acquired would be government overreach, analyzing on a regular basis to see if bigger companies have such agreements both within the industry as well as across other industries can allow the antitrust agencies to curtail the amount of power these extremely large companies have. For example, prohibiting any sort of agreement between Twitter and Facebook could be allowed to curtail any anticompetitive actions in the market. Along with this prohibition would come a hefty fine if violated in order to encourage the companies to abide by the policy? By taking such a stance, the actions of the businesses could be carefully monitored.

While normally a divestiture would represent less government interaction, in this case, all the acquisitions by

\footnotetext{
${ }^{165} I d$.

${ }^{166}$ See supra note 58.

167 See supra note 63.

${ }^{168}$ See supra note 39.

169 See supra note 1.
} 
these tech-companies up to this point have been approved by the FTC or DOJ or were not required to be reported. Forcing a divestiture after these companies have spent years building up the acquired companies to what they are today, assuming all actions taken were legal, would be gross overreach by the government for reasons solely that the companies have managed to grow their businesses in an efficient manner. This is even truer if these companies have not been shown to be causing an economic harm to consumers by driving up prices or providing lower quality goods. While many of these proposed policies might be seen as government overreach, the amount of government involvement required could arguably be said to not outbalance the benefits to the effectiveness in protecting free competition in the marketplace. The nature of the possible dichotomy between the two demands of antitrust laws can be seen by the two extremes on the position. On the one side, there are those who see the existence of the antitrust laws themselves as being an overreach of government involvement in the economy of the country. On the other hand, others think that the government should do all it can to ensure that there is fair competition within the marketplace, possibly through the use of excess regulations.

Neither of these extreme positions are plausible for the agencies to attempt to follow. Instead, the agencies must constantly search to secure a solid middle ground between the two sides. While much improved, it could be reasonably argued that the Merger Remedies Manual still has policies that prove to be lacking in maintaining the balance of both sides. The proposed policy changes above would help the DOJ and the FTC to better secure a balance between limited government involvement and protection of competition in the marketplace.

\section{CONCLUSION}

Antitrust laws have always been the subject of much debate and concern. While protecting and ensuring active competition of the marketplace is important, so is the liberties granted in the constitution that allows market participants to participate to their fullest. ${ }^{170}$ While battling with maintaining a balance between these two ideologies, various points of time throughout history have taken various approaches. While at one time mergers, which can allow one company to obtain full control of an industry, were rarely curtailed under the DOJ and the FTC, the two agencies have recently been more proactive in handling such cases. While there has been a renewed reliance on antitrust laws, the two agencies have still striven to maintain the balance between the two, a balance that has proven to be trying with the rise of big-tech.

While the DOJ's new manual on merger remedies does a better job at preserving the balance between the two ideologies than the FTC, especially through the allowance of private equity firms, the DOJ manual still has improvements that could be made both in regard to merger remedies and to merger appraisals in order to better ensure competitiveness in the marketplace. Required reviews of high risk divestment purchases, including high risk private equity buyers, does a better job at encouraging companies to competitively participate in the marketplace without being overly involved with the companies for long periods of time. Along with better monitoring for private equity buyers, changing the requirements for the report of a merger under the HSR to include companies valued over a certain amount will do a better job of catching any mergers that could be anticompetitive and stop government intrusion into companies after mergers have happened. The most important factor to consider with action taken towards big-tech as well as taken towards newer concerns in the antitrust arena is making sure than any action taken does not because a disruption in the balance between preserving competitive marketplaces and protecting consumers from anticompetitive measures and making sure the government refrains from overstepping into the private sector.

$--0-$

${ }^{170}$ See supra note 39 , at pg.1. 